\title{
COVID-19 threat projection and Its influence toward national defense system
}

\author{
Amarulla Octavian ${ }^{1}$, Syamsunasir $^{2 *}$, and Nadiva Awalia Rahmah ${ }^{2}$ \\ ${ }^{1}$ Maritime Security Study Program, National Security Faculty, Republic of Indonesia Defense University, Sentul IPSC area, \\ Tangkil Village, Citeureup District, Bogor 16810, Indonesia \\ ${ }^{2}$ Disaster Management Study Program, National Security Faculty, Republic of Indonesia Defense University, Sentul IPSC area, \\ Tangkil Village, Citeureup District, Bogor 16810, Indonesia
}

\begin{abstract}
The covid-19 pandemic that is currently experienced throughout the world has led to great uncertainty upon public health and the national economy. The impact of the Covid-19 pandemic has shaped the strategic environment landscape with four distinct attributes that might threaten a nation's survival, namely volatility, uncertainty, complexity, and ambiguity (VUCA). Thus, the government is expected to be able to make a swift and timely decision in responding to various threats in the VUCA era. Against the background, this paper discusses issues on global threat projection (especially the Covid-19 pandemic) and its influence on the national defense system, the re-actualization of the Total Defense System in the VUCA era, and the implementation of the Total Defense System in responding to the threats dynamic. To discuss the topic, this study analyzed the influence of global threats resulting from the Covid-19 pandemic on the national defense system, and how the Total Defense System is re-actualized and implemented in the VUCA era. The theoretical foundations employed in this study are securitization, neo-Malthusian, food security, dan society empowerment theories. The changing shape of threats has to be paid careful attention in formulating policy on the national defense system. In line with the complexity of threat characteristics in the VUCA era, the "re-actualization" of the Total Defense System has become an urgency given the current context. Against the dynamics of the current threats, the implementation of the Total Defense System could be examined from national food resilience and society empowerment factors. Total Defense System has to put people's roles at the forefront by guaranteeing the availability of necessities. By doing so, the people's loyalty in both national defense and the Total Defense System will improve along with people's welfare improvement.
\end{abstract}

\section{Introduction}

Before discussing the Covid-19 pandemic and its impact on the national defense system in depth, it is necessary to understand the concept of defense and security that Indonesia adopts. First, Article 30 Paragraphs 1 and 2 of the 1945 Constitution of the Republic of Indonesia stated that every citizen has the right and obligation to participate in the defense and security of the state, which is implemented through the Total Defense and Security System (Sishankamrata). The Indonesian Armed Forces and the National Police of the Republic of Indonesia are the main components in Sishankamrata, who are supported by the people. On the other hand, the Law of the Republic of Indonesia Number 3 of 2002 on National Defense and Law of the Republic of Indonesia Number 34 of 2004 on the TNI emphasizes that the national defense system is a Total Defense System that involves all people and other national resources.

\footnotetext{
* Corresponding author: syamsunasir@yahoo.com
}

This paper will elaborate on issues related to the projection of global threats (especially the Covid-19 pandemic) and their effects on the national defense system, the re-actualization of Sishanta in the VUCA era, and its implementation to face the dynamic threat landscape. Some of these problems are analyzed based on the relevant laws and regulations, along with several theories as to the analytical tools, that comprise securitization theory, neo-Malthusian theory, food security theory, and community empowerment theory.

\section{Global Threat Projection and National Defense System}

In the context of international relations, a state has to consider every changing situation and issue within its national, regional, and global strategic environment. Issues in the spotlight are part of a state's strategy to weaken other states or strengthen itself and to show that it 
can respond to various threats and safeguard its existence as a sovereign state. On the other hand, globalization has had a great impact on every dimension of life. In addition to military issues, the state has to pay careful attention to issues in ideology, politics, economy, socio-culture, technology, public safety, and legislation dimensions.

There are several shapes of strategic environment related to the national defense which has interrelated roles. The correlation between the environment and the national defense system is very important since national defense analyzes strategic environment at the national, regional, and global levels [1]. Thus, analytical skills are required to understand whether changes in the strategic environment that occur at the national, regional, and international levels could be considered threats

\subsection{Global Threat Projection (Covid-19 Pandemic)}

Based on the 2020 World Economic Forum (WEF) report [2], the Covid-19 pandemic (infectious diseases) had not been categorized as a serious threat compared to several other threats at the global level until the beginning of 2020. Meanwhile, the 2021 WEF report [3] reconsidered the risks related to the global pandemic, economic downturn, political turmoil, and climate crisis that continued to worsen throughout 2020. One of the major changes in the 2021 report compared to 2020 is the risks caused by the Covid-19 pandemic.

The risk posed by Covid-19 is ranked first in terms of its impact in 2021 Fig. 1, whereas the risk of infectious diseases was only ranked 10th in 2020 [3]. The WEF 2021 report also reveals that in the next few years there will be mass unemployment, social inequality, and a slowdown, and even a prolonged economic downturn that might lead to mass riots. This condition will lead to national stability disruption in all states, including Indonesia. A prediction also said that a sharp economic downturn will occur and trigger a global recession.
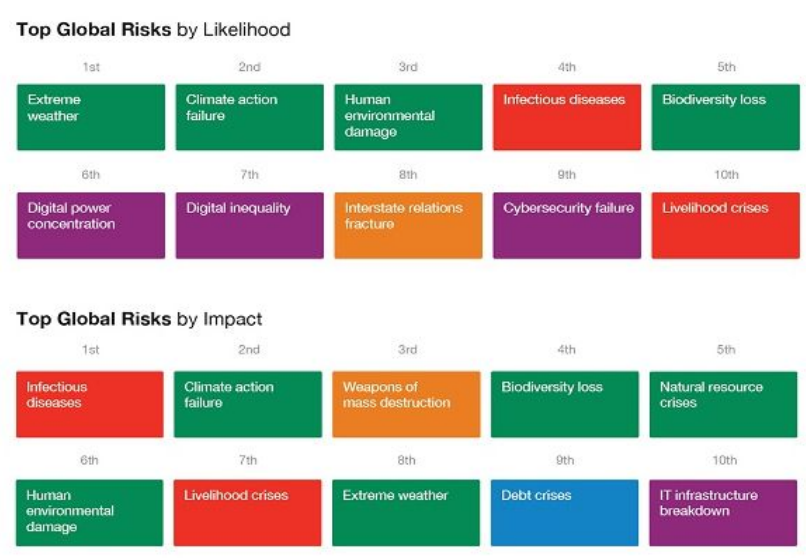

Fig. 1. 2021 Top Global Risk in terms of Likelihood and Impact [3].

A study of the risks posed by the Covid-19 pandemic showed that it is ranked as the 4th highest global risk in terms of likelihood and the 1 st highest global risk in terms of impacts. The global Covid-19 pandemic does not only affect public health and economic sectors, but also the political and defense/security sectors. Nevertheless, WEF still places environmental issues, such as extreme weather, failures in adaptation and mitigation, and natural disasters as the main threats in the long term. In other words, the Covid-19 pandemic and environmental issues are real threats to the sustainability of life on earth.

According to Fig. 1, interstate relations fracture is ranked as the 8th highest global risk, while the impact of weapons of mass destruction is ranked in the 3rd place. Then, extreme weather and its effects are classified as a major threat. Therefore, states need to carry out international cooperation to mitigate those threats.

\subsection{The Influence of Global Covid-19 Pandemic Threat toward National Defense System}

Threats of military or geopolitical nature are currently predicted to be relatively less likely to occur than environmental and social threats. Therefore, a redefinition of the defense or security system concept is required. Against this need, securitization theory could be employed as a new framework for analyzing (nonmilitary) security issues [4]. Securitization theory criticizes the traditional security paradigm which is too state-centric and military-centric by suggesting four sectors, namely: military, environmental, economic, social, and political [5]. Securitization can simply be understood as a process that places a non-security issue as a security issue.

In this case, the first-order effects of the Covid-19 pandemic and its derivative impacts such as mass unemployment, massive demonstrations, and food scarcity are issues that threaten national defense/security. As a response to these issues, states can no longer prioritize the use of militaristic methods or the deployment of armed forces. On the other hand, if a policy is implemented using a securitization approach, the government will treat ordinary-classified issues as threats to public safety and the nation's survival. These issues/threats only require reasonable action without any repressive military action.

Indonesia adopts a Total Defense System that involves all citizens and other national resources. In the context of the Covid-19 pandemic, the Total Defense System could no longer only use the power of the people as the last layer of defense. On the contrary, people who experience difficulties in life as a result of the rapid changes in the VUCA era might be a threat to the survival of the nation. Therefore, Sishanta must be oriented towards the development of people's capability to anticipate and face various socio-economic and political problems in the future. Thus, the threat to the nation's survival has become broader in scope.

Threats beyond the military dimension have even become a serious concern, where many countries have undergone securitization. Securitization itself operates in three spectrums: First, a non-politicized spectrum in which state does not attempt to address an issue; Second, the spectrum of politicization (politicized) in which state 
manages issues using ordinary means; and Third, the spectrum of securitization (securitized) where an issue is perceived as a security issue. The securitization spectrum depends on the securitizing actors who have the authority to declare an existential threat through a speech act against particular referent objects [6].

Securitization on non-military threats (such as the Covid-19 pandemic and climate change) can be classified as real threats. In its Defense White Paper or what is known as the Quadrennial Defense Review (QDR) 2014, The United States classified the threat of climate change as a threat to national security [7]. In responding to threats against the national defense, Indonesia uses a multiagency approach. The government mandates ministries and agencies other than the defense sector as the leading sector or the main element to deal with non-military threats (Law of the Republic of Indonesia Number 3 of 2002 Article 7 paragraph 3). This indicates that the state has realized that threats to national defense do not only come from military threats, but also non-military threats.

Changes in the global threats landscape also indirectly affect decision-makers in various countries in determining their internal threats since changes in the nature and form of global threats could trigger conditions of uncertainty and disruption. Disruption does not only mean the phenomenon of changes that occur today but also reflects the meaning of the future change [8]. The Covid-19 pandemic has become a global threat and disrupted various sectors of life. Thus, it needs to be responded to by placing it as a threat to national defense.

Indonesia has gradually adopted the concept of human security. In this concept, the scope of security is no longer narrowed to state security that is monopolized by certain apparatus (actors) but becomes wider by taking into account the security of the people. Issues related to security are becoming more multi-sectoral and comprehensive, such as food and energy security. Thus, security sector management becomes more participatory because it involves many institutions. Therefore, synergy and solidity from various actors such as the armed forces, police, intelligence agency, immigration agency, academics, and other stakeholders are the building block of national defense against this kind of threat.

The spectrum of security also needs to be broadened. If so far security issues categorized as "domestic security" only include social unrest, inter-group conflict, armed insurgency, and armed separatist movements; then the category has to be broadened up to include poverty, difficulties to access clean water and food sources, disease outbreaks, increasing unemployment, and other social problems. These issues are considered threats to human life and therefore must be seen as threats to the state. The state is obliged to protect its people from various threats that might endanger their lives.

Against the aforementioned argument, efforts to build security have shifted from the concept of "security against" to "security with." Thus, cooperative security, confidence-building measures, and preventive diplomacy carried out both at the bilateral and multilateral levels are also parts of the effort to answer this problem. As a consequence, Sishanneg also needs to be prepared in a framework to deal with various global threats, such as the
Covid-19 pandemic, climate change, natural disasters, and environmental damage.

\section{Re-actualization of Total Defense System in VUCA Era}

For the Indonesian people, the Total Defense System is the embodiment of the national defense system because it involves the armed forces as the main component as well as the people and other national resources as supporting components. Along with the development of the strategic environment, it is necessary to review the Sishanta concept. The validity of the Total Defense System concept has been proven in resisting colonialism in the pre and post-independence eras. However, in line with the changing dynamics of threats, especially in the VUCA era which is characterized by uncertainty and disruption, it is necessary to re-actualize the Total Defense System concept.

\subsection{Re-actualization of Total Defense System}

Re-actualization of the Total Defense System is very important, not only for decision-makers but also for all stakeholders. In the past, only certain elites understood defense/security issues. Today, the monopoly of defense/security issues is no longer appropriate to be practiced. The current democratization system in organizing the wheels of government has become a necessity, and defense issues have become the public domain. Moreover, issues related to defense systems cannot be in a vacuum or constant, since they are also closely linked to environmental changes. National defense is largely determined by various factors surrounding it [9].

The defense system cannot be separated from the problem of modernizing the Main Weapons and Equipment System. Nevertheless, another issue that is no less important, especially when the non-military defense is increasingly decisive in building a country's defense posture, is the involvement of other defense components, namely human resources, natural and artificial resources, and other national facilities and infrastructure. Therefore, the attention of defense planners has changed from the calculation of armed forces strength (hard power) to nonarmed forces strength (soft power).

Furthermore, to defend the nation from various threats, Sishankamrata and the Total Defense System are also original and genuine concepts from Indonesia. Therefore, there are two choices that Indonesia might take to deal with the dynamics of the threats, namely: redefinition or re-actualization. If redefinition is chosen, then the mandate in the 1945 Constitution of the Republic of Indonesia has to be amended along with Law Number 3 of 2002 and Law Number 34 of 2004. In the end, reactualization is an option that needs to be chosen, considering that every country has its differences in historical and cultural aspects.

When change has become a certainty (on the one hand) and the desire to maintain intrinsic values is very strong (on the other hand), then the best middle way is to 
re-actualize. In principle, re-actualization is to ensure the relevance of what is considered as a value in a system and ensure that it is not obsolete over time. History has also proven that Sishankamrata, which is supported by the people, was enabled Indonesia to gain its independence and defeat the colonials.

As a system that underlies defense and security policies, the concept of Sishankamrata still needs to be preserved despite the rapid changes in the legal and operational environments. In terms of spirit, the concept of Sishankamrata at least cannot be separated from the historical characteristics of the defense politics of the Republic of Indonesia. When most of the articles in the 1945 Constitution were amended, the concept of Sishankamrata was still maintained as stated in Article 30 Paragraph 2 of the 1945 Constitution.

The Total Defense System Doctrine places the people as the last resort of national defense to deal with various threats. People should be at the forefront of national defense since they are important parts of the national defense system. The Covid-19 pandemic is a real and actual example in which civilians are the ones who possess the competencies to deal with this threat. On the other hand, people still face various problems in their lives so they need to be more empowered by understanding them from a contemporary (contextual) perspective.

Besides calculating the need to increase military defense capabilities in dealing with threats, the evolution of threats dynamics in the fast-paced (disruptive) and uncertain VUCA era also requires changes in military strategy. Threats to national defense change rapidly and become increasingly uncertain like the "Volatility" and "Uncertainty" nature in VUCA. Science and technology development have also driven the change in defense characteristics of a nation. If defense threats in the past were always aimed at external enemies that possess certain military capabilities, now defense threats could be in the form of disease outbreaks, food scarcity, environmental damage, economic recession, and others. These non-traditional threats have also resulted in the development of various unconventional weapons types.

\subsection{Total Defense System in VUCA Era}

The changing forms of threats require a state to emphasize the role of supporting components in the Sishanta concept, which consists of defense components other than the military. In other words, it is not only military readiness that a state must prepare, but also various aspects beyond the military defense sector, ranging from ideological to economic matters. This means that the battlefield is getting broader, which ranges from physical war (hard power) to non-physical war (soft power). Due to the increasing complexity of threats toward national defense and the insufficient capability of the armed force, defense components other than the military have to play a bigger role in national defense.

This necessity is also in line with Article 7 Paragraph 3 of Law Number 3 of 2002 which stated that national defense system in dealing with non-military threats places government institutions other than the defense sector as the main element according to the form and nature of the threats, with the support of other national power elements. Strengthening government institutions other than the defense sector has also become one of the general defense policies, as stated in Article 2 Paragraph g of Presidential Regulation Number 8 of 2021 on the National Defense General Policy for 2020-2024. The document stated that one of the mid-term national defense priorities is to improve non-military defense capabilities carried out by ministries/agencies other than the defense sector.

Sishankamrata and Total Defense System is a total defense concept that is equal to the concept of total war in terms of the purpose and force mobilization. It is total, meaning that it uses all elements of national power, including natural and artificial resources, human resources, as well as national infrastructure and facilities. The people's role in national defense is also nonnegotiable. National defense is essentially all defense efforts that are universal in nature and implemented based on the awareness of the rights/duties of citizens and belief in the nation's power (Article 2 of Law Number 3 of 2002).

For this reason, the law emphasizes the need for Reserve Components with high readiness be deployed anytime and anywhere. Reserve Components are national resources that are prepared and deployed through mobilization to reinforce the main components' capabilities (Article 1 paragraph (6) of Law Number 3 of 2002). Currently, no law specifically regulates Reserve Components and Supporting Components, but Law Number 23 of 2019 on National Resources Management for National Defense could be used as the legal basis for preparing Reserve Components and Supporting Components to carry out national defense duties.

The bill for Reserve Components and Supporting Components has also been prepared and has been discussed several times, but has not been passed into law due to rejections from several elements of society. By far, the law on Reserve Components has not been prioritized to be enacted in the near time. Another issue that hinders the law's enactment is the magnitude of globalization and the free market's influence in current national affairs. The strong market logic has shifted the logic of the national interest of each economic actor, both within and outside the government. As a result, the rhetoric about the importance of preparing national defense stands out more than reality.

Nevertheless, Law Number 23 of 2019 still can be used as the legal basis for preparing the Reserve Components and Supporting Components [10] as national resources. Komcad which consists of human resources, natural and artificial resources, and national infrastructure and facilities are spread throughout Indonesia. This condition urges the necessity to develop those national resources in an integrated manner to be reliable Reserve Components with capabilities to defend the entire territory of the Republic of Indonesia as a defense unit.

Indonesia's national defense capability can be measured based on the level of community welfare, which is viewed from three criteria, namely: poverty, education, and unemployment. If these criteria are in a good state, it will indirectly improve Indonesia's national defense 
capabilities. In other words, improving people's welfare is directly in line with the improvement in national defense capability. Thus, both aspects have to be prepared simultaneously, and the fulfillment of people's basic needs is the priority. By doing so, people's loyalty to participate in national defense efforts will grow.

Efforts to improve people's capabilities in the Total Defense System are part of the national development goals. In the current VUCA era, people are not able to participate as national defense components in the Total Defense System if their lives are still far from a decent standard of living. Furthermore, the neo-Malthusian theory argued that the increase in population is in line with a decrease in food reserves. Such conditions can trigger communal conflicts to fight over scarce resources, especially necessities such as food. The scarcity of natural resources might potentially increase the risk of conflict [11]. Therefore, the re-actualization of Sishanta in the VUCA era is very important, especially the state's ability to prepare people as national defense components through the improvement of their living standards.

\section{Total Defense System Implementation Against the Threat Dynamics}

In the previous discussion, the Covid-19 pandemic that threatens national life could be categorized as securitization. According to the Copenhagen School [4], securitization is an extraordinary measure that turns a (non-security) issue into a security issue. The Covid-19 pandemic, which has hit all countries, is expected to last for a long period and has implications on the global food resources availability. For this reason, Indonesia needs to prioritize efforts to improve food resources available to ensure national food security.

The importance of food resources availability and provision was also expressed by Basundoro and Sulaeman in their research "Meninjau Pengembangan Food Estate Sebagai Strategi Ketahanan Nasional pada Era Pandemi Covid-19" (Review of Food Estates Development as a National Security Strategy in the Covid-19 Pandemic Era). The study concluded that the Covid-19 pandemic was a multi-dimensional phenomenon that could disrupt various strategic sectors, including the food security of a nation. The lack of food reserves availability owned by the state could lead to communal conflict that might threaten national stability. The food estate project is an embodiment of the national food security strategy [12]. Similar to this study, both studies view the Covid-19 pandemic as a threat that could disrupt various vital sectors related to people's lives, especially the national food security. In this case, the author views the necessity to develop national food security through the implementation of a protracted war concept to fulfill logistical support (especially food) in all regions during a long period.

For this reason, the implementation of the Total Defense System is closely related to the condition of national food security, the urgency of the food estate project, and community empowerment. These factors represent the core aspects of Total Defense System implementation to deal with various threats. The threat in question is related to the Covid-19 pandemic and several other threats that have been mentioned in the $2021 \mathrm{WEF}$ Report as discussed in the previous section.

\subsection{Food Security}

Determining development priorities to achieve food security is very important since global level issues with high impact and likelihood of occurrence are water crises, food crises, and infectious diseases [3]. For the Indonesian context, the availability of water has not become a crucial or critical issue. On the other hand, infectious disease (especially Covid-19) has become a crucial issue because it has turned into an epidemic that caused many people to suffer and die. The COVID-19 pandemic has hit and disrupted all sectors of people's lives, including one of the most strategic, namely food security. In the end, the production and distribution of community food are disrupted. The Food and Agriculture Organization (FAO) even said that the COVID-19 pandemic impact could lead to a food crisis [13]. Likewise, national food security experiences ups and downs from time to time, so the Covid-19 pandemic can become a serious threat multiplier to national food security.

The covid-19 pandemic has disrupted the national food logistics system due to limited food logistics activities during the pandemic. The disruption of the food supply chain causes difficulties in people's food accessibility, thus threatening their lives. It is also feared that the uneven food distribution could lead to a disparity, where one or few regions experiences an excess of food commodities while the other experiences shortage.

Food security is closely related to national defense/security. This view has been recognized since ancient Egypt. In the case of Sishanta, Indonesia relies on its national resources to support national defense, including national food availability. The four pillars of food security include availability, accessibility, utilization, and stability [14]. For this reason, the Total Defense System will be effective if the state of national food resources fulfills these four pillars. Indonesia itself is in the category of a country with "serious risk" in terms of national food security. This condition indirectly reduces the nation's defense capability based on the support of people's power.

The Covid-19 pandemic does not directly disrupt the availability of national food, but it affects food distribution and even bans the import/export of food resources at the global level. Indonesia's food security is one of the emerging domestic (geopolitical) issues, where the management is still far from perfect. On the other hand, Indonesia has a large population (more than 270 million), which has large demands for food resources.

Without food security, especially in terms of availability and accessibility, people within a community will experience insecurity in terms of inadequate nutrient intake, which might potentially cause mass starvation. Such conditions could drive people to conduct social movements or large-scale demonstrations demanding changes to the government. In other words, the 
government could be deemed to fail if it is unable to fulfill the basic food necessary for its people. General Thucydides, military leaders, and historians from the Ancient Greek era explained that food security is a crucial issue and even becomes an important aspect for the continuity of a government [15]. Until now, the issue of food security remains a major concern for policymakers around the world, especially during the Covid-19 pandemic that is being experienced globally.

\subsection{Food Security}

As a supporting component in Sishanta, it is necessary to improve people's life and skills through empowerment measures to enable them to participate in national defense. In essence, community empowerment is not only aimed at individuals, but also in the community. For this reason, the people/community can be used as a normative benchmark, which places the concept of community empowerment as a part of efforts to build the existence of individuals, families, and even the nation as a realization of just and civilized humanity. Community empowerment activities require an understanding of human nature to enrich insight in applying various concepts or empowerment programs to the people.

History has proven that a nation that only relies on its natural resources without developing its human resources will never become a great nation. On the other hand, nations with limited natural resources but has qualified human resources were able to become developed and independent nations. Thus, improving human resources quality is a necessary condition for national development. If this is fulfilled, our nation can be looked at and visited by foreign experts.

Community empowerment programs or activities will not run properly without the support of other national resources, especially the availability of natural resources as the agricultural and maritime nation's greatest wealth. Indonesia possesses renewable and nonrenewable natural resources, such as oil, minerals, gas, and other mining commodities. Because these resources are one of the main factors to support community empowerment programs, these potentials should be explored in a controlled manner with strict adherence to sustainable development principles to ensure environmental balance and sustainability. One of the principles of community empowerment is based on the regional potentials and a healthy environment. Thus, the management and development activities must strictly adhere to the principles of sustainable development and environmental conservation for the benefit of all Indonesian people in the present and the future.

\section{Conclusion}

Based on the discussion on the projected threat of the Covid-19 pandemic against the Total Defense System, several conclusions were drawn. First, global threats are always changing from time to time. The Covid-19 pandemic has caused various negative impacts on a global scale. Changes in global threats also indirectly affect decision-makers in defining internal threats within each state. Threats changes have to become a concern in national defense system policies formulation. Second, in line with the increasingly complex nature of threats in the VUCA era, the "re-actualization" of the Total Defense System has become an urgent need in the current context. If in the past, the so-called threats to national defense always came from external enemies that possess a certain level of military capabilities, the current forms of threat are much broader than that. Threats to national defense in the current context could be in the form of disease outbreaks, food scarcity, environmental damage, economic recession, and other nontraditional threats. Third, the implementation of the Total Defense System to deal with the dynamics of the threats could be viewed from the national food security and community empowerment aspects. With an adequate level of national food security and social welfare, people will have a high level of resilience to improve their understanding of their roles in national defense as well as their capacity to perform their roles in the Total Defense System.

\section{References}

1. B. Bandoro. States Choice of Strategies. Yogyakarta: Graha Ilmu (2014).

2. WEF. The Global Risks Report 2020. http://www3.weforum.org/ docs/WEF_Global_Risk_Report_2020.pdf (2020).

3. WEF. These are the world's greatest threats in 2021. https://www. weforum.org/agenda/2021/01/these-arethe-worlds-greatest-threats-2021/ (2021).

4. B. Buzan, O. Waever. Regions and Powers: The Structure of International Security, Cambridge: Cambridge University Press, (2003).

5. A. Alfajri, Setiawan, H. Wahyudi. Synergy of Regional Defense Spatial Development in Facing Non-Military Threats in Indonesia, Jurnal Global and Strategis. 13 (2019).

6. 6. R M. Lutfi. Non-military Defense Against a Pandemic. Indonesian Defense White Paper (2020).

7. QDR. Quadrennial Defense Review. USA: Department of Defense (2014).

8. R. Kasali. Disruption. Jakarta: Gramedia Pustaka Utama (2017).

9. I. Samego. Contextualization of 'Sishanneg': Empowerment of Defense Areas in a Changing Perspective. Journal of Defense 5, 1, 1-14 (2015).

10. B. T. Sofyan. Development of Aerospace Potential in the Context of Empowering Air Defense Areas. Potdirga National Seminar, Bidakara Ballroom, Pancoran Jakarta (2020).

11. T. Bernauer, T. Böhmelt, V. Koubi. Environmental changes and violent conflict. Environmental Research Letters 7, 1, 015601. (2012).

12. A. F. Basundoro \& F. H. Sulaeman. Mininjau Pengembangan Food Estate Sebagai Strategi Ketahanan Nasional Pada Era Pandemi Covid-19. Conference. Jakarta: Lemhannas (2020). 
13. SDGs-Indonesia. Pentingnya Menjaga Ketahanan Pangan di Masa Pandemi COVID-19. https://localisesdgs-indonesia.org/beranda/v/ pentingnya-menjaga-ketahanan-pangan-di-masapandemi-covid-19 (2020).
14. Food and Agriculture Organization (FAO). Impacts of coronavirus on food security and nutrition in Asia and the Pacific: Building more resilient food systems, 9. Bangkok. (2020).

15. A. Burn. The Pelican History of Greece, 297-299, London: Penguin (1982) 